\title{
Teollisuuden murros OECD-maissa
}

\author{
Raimo Lovio
}

Nykyisessä yhteiskuntapoliittisessa keskustelussa pidetään selvänä, että kehittyneiden kapitalististen maiden taloudessa ja ehkä maailmantaloudessa kokonaisuudessaankin tapahtui 1970-luvun aikana jonkinlainen murros. Murroksen seurauksena 1980- ja 90-luvut tullevat muodostumaan erilaisiksi kuin 1950- ja 60luvut. Keskustelussa vilahtelevat sanat öljykriisi ja pitkät aallot, mikroelektroniikka ja automaatio, vanhat ja uudet teollisuusmaat, informaatioyhteiskunta ja työyhteiskunnan kriisi . . .

Kuitenkin on hyvin vaikea muodostaa täsmällistä kuvaa siitä mitä tarkkaan ottaen on tapahtunut. Visiot vaihtelevat ja faktoja esitetään niukalti. Kuitenkin kun murroksen puhkeamisesta on nyt jo kymmenkunta vuotta, alkaa olla edellytyksiä kuvan terävöittämiseen teorioiden ja visioiden lisäksi myös taloustilastojen avulla. Edelleenkin on tosin kysymys palapelistä, jossa reunapalikoita ja etenkin kulmapalikoita on kiusallisen vähän.

Seuraavassa yritän koota palapeliä kolmenlaisten palasten avulla. Aluksi esitän muutamia paloja OECD-maiden teollisuuden kasvusta ja työllisyydestä, sitten palasia teollisuuden teknologisesta murroksesta ja lisäksi vielä muutaman palasen kansainvälisessä teollisessa työnjaossa tapahtuneista muutoksista. Korostan, että näkökulmani on teollisuus- ja OECDmaailmakeskeinen. ${ }^{I}$

\section{Kasvuvauhdin nopea hidastuminen}

Ilmeisimpiä tosiasioita viimeisten vuosien kehityksessä on teollisuuden kasvuvauhdin nopea hidastuminen. Tärkeimpien OECD-maiden osalta tämä näkyy taulukosta 1 , jossa on tarkasteltu tehdasteollisuuden tuotannon reaalisia vuotuiskasvuja viisivuotisperiodeittain

1 Tämä artikkeli on kirjoitettu taustajutuksi Tarmo Lemolan johtamaan tutkimusprojektiin "Suomen teollisuuden innovaatiotoiminta ja uudistuminen".
1965-84. Vuosina 1965-74 teollisuus kasvoi tarkastelussa mukana olevissa maissa keskimäärin $6 \%$ vuodessa, mutta vuosina 197584 vain $1,5 \%$. Kasvuvauhti on siis pudonnut neljäsosaan.

Olennaista on myös havaita, että Japania ja eräitä pieniä maita lukuunottamatta (Ruotsi, Sveitsi, Hollanti ja Suomi) kasvu on 1980luvun alkupuolella ollut vielä hitaampaa kuin 1970-luvun jälkipuoliskolla. Varsin useassa maassa teollisuustuotanto on polkenut 1980luvulla paikallaan vuoden 1982 lopulla aallonpohjan saavuttaneen laman seurauksena. Vuoden 1982 lama oli lähes yhtä syvä kuin ns. ensimmäisen öljykriisin jälkeinen lama 1970-luvun puolivälissä. Tämä vahvistaa käsitystä, ettei 1970-luvun lamassa todellakaan ollut kysymys satunnaisesta onnettomuuksien summasta, vaan että on tapahtunut pysyvämpi teollisuuden kasvutyypin muutos.

Kasvuvauhdin hidastumista arvioitaessa on luonnollisesti otettava huomioon, että kasvu oli 1960-luvulla ja 70-luvun alussa epänormaalin nopeaa. Osin kasvun hidastumisessa on siis kysymys vain paluusta pidemmän aikavälin keskimääräistasolle. Lisäksi olisi muistettava, että tasaisen prosenttikasvun ylläpitäminen vuodesta toiseen merkitsee itse asiassa absoluuttisina lukuina tarkasteltuna kiihtyvää kasvua. Esimerkiksi Suomessa $3 \%$ :n teollisuustuotannon lisäys vuonna 1984 vastaa hyvinkin $6 \%$ :n tuotannon lisäystä vuonna 1965. Kasvuvauhdin hidastuminen vuoden 1974 jälkeen on kuitenkin OECD-maissa ollut niin huomattava, että Irlantia lukuunottamatta tuotannon lisäys on vuosina 1974-84 ollut absoluuttisestikin pienempi kuin vuosina 1964-74.

Teollisuuden kasvuvauhti on vaihdellut suhteellisen paljon maasta toiseen. Koko periodilla 1964-84 kasvu on ollut selvästi nopeinta Japanissa. Huomattavan nopeaa kasvu on 
Taulukko 1. Tehdasteollisuuden tuotannon reaalinen vuosikasvu OECD-maissa 1965-1984, \%

\begin{tabular}{|lcccc|}
\hline Maa & $1965-69$ & $1970-74$ & $1975-79$ & $1980-84^{2}$ \\
Yhdysvallat & 6,5 & 3,3 & 3,8 & 1,6 \\
Japani & 13,8 & 7,0 & 3,6 & 4,0 \\
Saksan It & 5,5 & 2,8 & 2,1 & $-1,1$ \\
Ranska & 5,0 & 4,6 & 1,6 & $-0,9$ \\
Englanti & 2,8 & 1,8 & 1,9 & $-1,3$ \\
Sveitsi & 4,9 & 3,7 & $-1,1$ & 1,9 \\
Hollanti & 6,5 & 5,4 & 1,2 & 1,7 \\
Ruotsi & 5,3 & 4,2 & $-0,7$ & 2,1 \\
Belgia & 5,1 & 4,8 & 1,2 & 0,4 \\
Italia & 7,0 & 5,0 & 2,5 & $-1,1^{4}$ \\
Kanada & 6,5 & 5,3 & 2,6 & $-0,2$ \\
Australia & 4,6 & 4,2 & 3,0 & $-0,7$ \\
Itävalta & 5,8 & 6,9 & 2,5 & 1,0 \\
Norja & 4,4 & 4,7 & $-0,8$ & $-0,3$ \\
Suomi & 7,0 & 7,5 & 2,0 & 3,8 \\
Irlanti & 6,4 & 5,0 & 5,7 & 4,3 \\
Kreikka & 8,8 & 10,1 & 6,0 & $-0,9$ \\
Espanja & 12,4 & 11,2 & 0,6 & $-0,5$ \\
Keskimäärin & 6,6 & 5,4 & 2,1 & 0,8 \\
\hline
\end{tabular}

$1=$ luvut on laskettu indeksisarjasta, jossa perusvuosi on 1980 .

$2=1984$ tieto koskee vuoden II-neljännestä.

$3=$ koko teollisuus.

$4=$ vuodet $1980-83$.

Lähde: OECD: Main economic indicators. Historical statistics 1964-1983. Paris 1984 a ja OECD: Main economic indicators, October 1984. Paris 1984 b.

ollut myös sellaisissa jäljessä tulevissa maissa kuin Kreikka, Espanja, Irlanti ja Suomi.

Ehkä mielenkiintoisempaa on kuitenkin katsoa, minkä maiden teollisuus on toisaalta vähiten ja toisaalta eniten menettänyt kasvunopeuttaan. Jos verrataan eri maiden kasvua vuosina 1974-84 kasvuun vuosina 1964-74, saadaan tulokseksi, että aikaisempaan kas- vuunsa nähden vähiten kasvunopeuttaan ovat menettäneet Irlanti, Yhdysvallat, Suomi ja Japani. Merkille pantavaa tässä on ennen kaikkea Yhdysvaltain teollisuuden suhteellisen hyvä menestys, koska 1960-luvulle oli tyypillistä päinvastoin se, että monet maat kuroivat vähitellen umpeen Yhdysvaltain taloudellista ja teknologista etumatkaa. Yhdysvaltain teollisuuden kasvua viime vuosina ovat kiihdyttä- 
neet mm. sisäinen rakennemuutos (kasvun painopisteen siirtyminen ns. aurinkovyöhykkeelle ja Kaliforniaan), valtavat budjettialijäämät ja dollarin uusi vahvistuminen.

Kovimmin murroksen puhkeaminen on koetellut Espanjan, Australian ja Norjan teollisuutta, joissa tuotanto on suoranaisesti laskenut vuoden 1974 jälkeen. Norjan tilanteeseen on vaikuttanut kasvun suuntautuminen öljysektorille (ks. Economic growth ... 1984, 124-150). Varsin voimakkaasti on hidastunut myös suurten EEC-maiden, Ranskan, Englannin, Saksan liittotasavallan ja Italian, teollisuuden kasvu. Teollisuuden murroksen vaikutukset näyttävätkin näkyvän erityisen voimakkaina Euroopan vanhoissa teollisuusmaissa.

\section{Teollisuuden osuus kansantaloudessa kääntyy laskuun}

Teollisuuden kasvun hidastumisen seurauksena sen kansantaloudellinen suhteellinen merkitys on kääntynyt laskuun, jos teollisuuden kansantaloudellista merkitystä mitataan tavanomaiseen tapaan sen osuudella bruttokansantuotteesta ja työllisyydestä.

Koko OECD-alueella tehdasteollisuuden osuus bruttokansantuotteesta kääntyi laskuun jo 1960-luvulla ja osuus työllisyydestä vuonna 1970. Vanhemmissa teollisuusmaissa osuuden lasku alkoi jo aikaisemmin. Mutta esimerkiksi Suomessa tehdasteollisuuden osuus bruttokansantuotteesta saavutti huippunsa vasta vuonna 1974 ja osuus työllisyydestä vuonna 1972 (ks. OECD 1984 c).

Palveluelinkeinot ovat jo pitkään useimmissa OECD-maissa työllistäneet enemmän kuin tehdasteollisuus. 1970-luvun murroksen erityispiirre on lähinnä siinä, että murroksen jälkeen varsin monessa maassa yksinomaan yhteiskunnalliset ja henkilökohtaiset palvelut (julkinen hallinto, opetus, tutkimus, tervey- denhoito, sosiaalihuolto, järjestötoiminta, kulttuuripalvelut ja kotitalouksia palveleva toiminta) työllistävät enemmän ihmisiä kuin tehdasteollisuus. Suomessa koko teollisuus työllisti enemmän kuin maatalous ensimmäisen kerran vasta vuonna 1966, mutta teollisuuden murroksen jälkeen jo vuonna 1983 yksinomaan yhteiskunnalliset ja henkilökohtaiset palvelukset työllistivät enemmän kuin teollisuus (ks. Työvoimakatsaus 3/84, taulukko 7).

Teollisuusvaltaisimpia OECD-maista ovat nykyisin Saksan liittotasavalta ja Japani, joissa tehdasteollisuuden osuus bruttokansantuotteesta on hieman yli $30 \%$. Suomessa osuus on $24 \%$, mikä on sama kuin koko OECDalueella keskimäärin (OECD 1984 c).

Teollisuuden suhteellisen osuuden supistumista on tunnetusti kuvattu siirtymiseksi jälkiteolliseen palvelu- tai informaatioyhteiskuntaan. "Informaatioyhteiskuntaan" meidän väitetään olevan siirtymässä siinä mielessä, että yhä suurempi osa ihmisistä - työskentelivätpä he millä talouden sektorilla tahansa työkseen lähinnä tuottaa, käsittelee tai jakaa informaatiota tai harjoittaa näihin liittyviä tukitoimintoja. Esimerkiksi Suomessa vuonna 1980 tilastokeskuksen laskelmien mukaan $30 \%$ ammatissa toimivista ihmisistä työskenteli ns. informaatioammateissa (Jeskanen-Sundström 1983). OECD:n luoma informaatioammattien luettelo on kuitenkin hyvin hatara; informaatioammatteihin kuuluvat mm. tutkijat, myyjät, lääkärit, työnjohtajat, tilintarkastajat, näyttämötaiteilijat, latojat ja postinkantajat ...

On myös vaikea ymmärtää miksi tiedosta olisi nyt yhtäkkiä tullut tuotannontekijä maan, työn ja pääoman rinnalle, kuten informaatioyhteiskunnan profeetat väittävät. Ihminen on kyllä tullut nokkelammaksi ja koneet tehokkaammiksi kuin ennen ja sikäli tiedon merkitys tuotannossa on kasvanut, mutta ei 
tieto sinänsä ole mikään uusi erillinen tuotannontekijä. Tiedon kasvu ja teknologinen kehitys ovat aina olleet tuotannon ja tuottavuuden kasvun tärkeitä lähteitä ja tieto vaikuttaa tuotannossa vain koneiden ja työvoiman laadun paranemisen kautta. Sitä paitsi olisi olennaista muistaa, että funktionaalisesti useimmat palveluelinkeinot ja informaatioammatit ovat aineellisesta tuotannosta irtaantuneita jatkeita. Yksinkertaistaen: jos aikaisemmin sata talonpoikaa työskenteli pelloilla henkensä ylläpitämiseksi, niin nyt pellolla on enää kymmenkunta, mutta eivät loput ole minnekään kadonneet. Osa tekee traktoreita ja lannotteita, osa kypsyttelee juustoa, osa kuljettaa tilatankkeja, kauppaa lihaa ja tarjoilee pöytään, osa tutkii hybridimaissia, osa hallinnoi maataloutta ja toimii tuottajajärjestöissä, niin ja kaiken huipuksi muutamat kirjoittavat maaseutuproosaa. Jos aikaisemmin sata oli pellolla rinnakkain, niin nyt nuo sata ovat päällekkäin korkeana pyramidina. Ja jos yksi pettää . . . Toisin sanoen maatalouden tuottavuuden kehittäminen on edellyttänyt teollisuuden kehittämistä ja teollisuuden kehittäminen edellyttää nyt $\mathrm{mm}$. tietotekniikan kehittämistä ja tutkimuksen laajentamista.

\section{Teolliset työpaikat vähenevät}

Teollisuuden merkitys ei supistu ainoastaan suhteellisesti vaan työvoimatarpeen osalta myös absoluuttisesti. Tuotannon hidastuneen kasvuvauhdin ollessa pienempi kuin työn tuottavuuden kasvuvauhti teollisuuden työvoimatarve vähenee.

Teollisuuden työvoima alkoi vähetä eräissä Länsi-Euroopan maissa jo ennen 1970-luvun murrosta. Tehdasteollisuuden korkeimmat työllisyysluvut saavutettiin mm. Sveitsissä, Hollannissa, Ruotsissa ja Englannissa jo 1960luvun puolivälissä. Saksan liittotasavallassa ja Japanissa työllisyys alkoi vähetä 1970-luvun alussa. Muissa OECD-maissa laskun alku ajoittuu 1970-luvun puoliväliin tai muutamaa vuotta sen jälkeen.

Taulukosta 2 tilanteen kehitys nähdään tarkemmin maittain. Vuodesta 1964 vuoteen 1974 tehdasteollisuuden työllisyys kasvoi vielä useimmissa maissa. Voimakkainta kasvu oli jäljessä tulevissa maissa, kuten Kreikassa, Suomessa, Kanadassa ja Irlannissa. Mutta vuodesta 1974 vuoteen 1984 tehdasteollisuuden työllisyys kasvoi enää vain Kreikassa. Li-

Taulukko 2. Eräiden OECD-maiden tehdasteollisuuden työllisyyden kehitys $1964-84,1964=100$.

$\begin{array}{lcr}\text { Maa } & 1974 & 1984 \\ \text { Yhdysvallat } & 116 & 113 \\ \text { Japani } & 117 & 109 \\ \text { Saksan lt } & 105 & 85 \\ \text { Ranska } & 102 & 82 \\ \text { Englanti } & 93 & 66 \\ \text { Sveitsi } & 90 & 71 \\ \text { Hollanti } & 88 & 66 \\ \text { Ruotsi }^{2} & 97 & 83 \\ \text { Italia }^{2} & 107 & 95 \\ \text { Kanada } & 121 & 100 \\ \text { Itävalta }^{3} & 107 & 89 \\ \text { Tanska }^{3} & 101 & 84 \\ \text { Norja }_{\text {Suomi }}{ }^{3} & 113 & 105 \\ \text { Irlanti }_{\text {Kreikka }}^{122} & 12, \\ \text { Keskimäärin }^{2} & 119 & 111 \\ & 134 & 161 \\ & 108 & 96\end{array}$

1 = tieto koskee vuoden 1984 II-neljännestä

$2=$ tehdasteollisuus ja kaivannaistoiminta

$3=$ koko teollisuus

Lähde: OECD: Main economic indicators. Historical statistics 1964-1983. Paris 1984 a ja OECD: Main economic indicators, October 1984. Paris 1984 b. 
säksi työllisyyden väheneminen oli useissa maissa varsin voimakasta. Suhteellisesti voimakkainta se oli Englannissa ja Hollannissa. Rajun laskun seurauksena kaikissa LänsiEuroopan vanhoissa teollisuusmaissa tehdasteollisuudessa oli vuonna 1984 vähemmän työvoimaa kuin vuonna 1964. Vähiten työllisyys on pudonnut Suomessa ja Yhdysvalloissa.

Teollisuuden kokonaistyöllisyyttä osoittavat luvut peittävät lisäksi alleen osan murroksen luonteesta. Suomen osalta voidaan esimerkiksi laskea erikseen toimihenkilöiden, työntekijöiden ja työntekijöiden todellisten työtuntien määrän kehitys vuosina 1973-83. Toimihenkilöiden määrä kasvoi tehdasteollisuudessa tänä aikana $21 \%$, mutta työntekijöiden määrä laski $6 \%$. Työntekijöiden työtunnit vähenivät vuodesta 1973 vuoteen $19829 \%$. Työntekijät tekivät tehdasteollisuudessa työtunteja vuonna 1982 vähemmän kuin 1960luvun lopussa (luvut laskettu Teollisuustilastosta, vuoden 1983 tiedot ovat ennakkotietoja).

Teollisuuden työvoimatarve vähenee melkoisella varmuudella seuraavanakin kymmenvuotiskautena. Kysymys on lähinnä siitä kuinka nopeana väheneminen jatkuu. Tuskin on odotettavissa mitään rajua putoamista, mutta varsin perustellulta vaikuttaa ennuste, että 1990-luvun alussa on Suomen teollisuudessa henkilökuntaa noin 30000 vähemmän kuin tällä hetkellä.

1970-luvun murroksen seurauksena teollisuus on siis alkanut maatalouden ohella vähentää työvoimaansa. Samaan aikaan palvelujen työvoimatarpeen kasvu on hidastunut. Ja koska kuitenkin työmarkkinoille tarjoutuva työvoima on edelleen hitaasti kasvanut, seurauksena on ollut työttömyyden räjähdysmäinen kasvu. Vuonna 1973 OECD-maissa oli yhteensä 10,2 miljoonaa rekisteröityä työtöntä, mutta vuonna 1983 jo 33,0 miljoonaa. Työttömyysaste koko OECD-alueella oli vuonna 1983 8,7 \% (OECD 1984 d, 104).

Tässä ovat varmaankin paljon puhutun työyhteiskunnan kriisin selkeimmät seikat. "Ideaalityyppinen" työ (suorittava, konkreettinen ja usein käden taitoa ja harjaantumista edellyttänyt teollisuustyö) vähenee ja työttömyys kasvaa.

\section{Elektroniikan soveltamiseen perustuva} kumous?

Edellä on käsitelty teollisuutta kokonaisuutena ja määrälliseltä kannalta. Asian toinen puoli on laadullinen ja rakenteellinen. Monet tutkijat pitävät 1970-luvun murroksen keskeisenä piirteenä teknologista murrosta, joka ilmenee ns. kasvualojen vaihtumisena ja useimmilla aloilla tuotantoprosessien murroksena. Tämän käsityksen mukaan olisi tapahtumassa siirtyminen vanhasta "teknologisesta systeemistä" uuteen "teknologiseen systeemiin". Teollisuuden kasvuvauhdin hidastuminen selittyisi mm. sillä, että vanhan "teknologisen systeemin" vetokyky on sammunut eikä uudella ole ainakaan vielä riittävän vahvaa vetovoimaa (esim. Freeman et al. 1982, sama kehiteltynä Perez 1983).

Useimmiten "teknologisen systeemin" muutoksen ytimen sanotaan liittyvän tietokoneisiin, tietoliikennevälineisiin, automaatioon, robotteihin ja mikro-elektroniikkaan, eli yleisemmin sanottuna elektroniikan soveltamiseen. Ja mikäli populaariin julkiseen keskusteluun olisi uskomista, niin näillä aloilla todella tapahtuu koko yhteiskuntaa mullistavia vallankumouksia harva se päivä. Erityisen paljon on viimeiset vuodet kohistu mikroelektroniikasta, noista salaperäisistä piisiruista, joiden on sanottu aiheuttavan milloin mitäkin. Vakavasti otettavassa tutkimuksessa tulisi kuitenkin huolellisesti pohtia, kuinka merkittävä murros elektroniikan laajamittainen soveltaminen todella on ja ajoittuuko tuo murros 
edes joltisellakin tarkkuudella 1970-luvulle. Ja jos, niin missä mielessä?

Merkittävien teknologisten murrosten ajoittamista vaikeuttaa murrosten pitkäaikaisuus. Yksittäiset luonnontieteelliset löydöt tai tekniset keksinnöt voidaan ajoittaa usein suhteellisen varmasti johonkin vuoteen, jopa päivään, mutta teknologisten murrosten läpivienti kestää nykyisessä nopeutuneessakin ajassa muutamia vuosikymmeniä. Suurissa murroksissa ei ole nimittäin kysymys yhdestä teknologisesta keksinnöstä ja sen yksinkertaisesta käyttöönottamisesta, vaan muutaman perusinnovaation pohjalta syntyvistä sadoista parannus-, täydennys- ja sovellutusinnovaatioista. Uuden teknologian käyttöönottoa hidastaa myös vanhan teknologian usein pitkäänkin jatkuva taloudellinen kannattavuus: uuden teknologian täytyy olla todella taloudellista ennen kuin vanha pääomakanta kannattaa nopeasti vaihtaa uuteen. Lisäksi monet institutionaaliset seikat hidastavat uuden teknologian läpimurtoa. Edellyttäähän voimakas teknologinen murros pääomien ja työvoiman siirtymistä alalta toiselle, valtion tukitoimenpiteiden uudelleensuuntaamista, muutoksia tutkimuksen ja koulutuksen painopisteissä jne. 1970-luvulla mahdollisesti yhteiskuntaa mullistaneiden teknologisten murrosten juurten täytyykin löytyä jo 1940- ja 50-luvuilta.

Elektroniikka on tällainen ala. Vuoden 1947 lopulla Bellin laboratoriossa työskennelleet tutkijat John Bardeen, Walter Brattain ja William Shockley kehittivät elektroniikan perusrakenneosan, transistorin. Transistoreita valmistettiin aluksi germaniumista, kunnes vuonna 1954 Texas Instruments kehitti piitransistorin. Transistoritekniikka alkoi nyt muodostaa uhkan elektroniputkitekniikalle, johon tosin vielä perustui ensimmäinen kaupallinen tietokone Univac 1 vuodelta 1951. Integroitu piiri, joka on puolijohdekomponentti, jossa on samalla komponentilla useita transistoritoimintoja, kehitettiin vuonna 1960. Vuonna 1963 Digital Equipment Corporation toi markkinoille PDP 5 -tietokoneen ja paria vuotta myöhemmin PDP 8 -tietokoneen. Näiden myötä syntyi käsite pientietokone, sarjavalmisteinen, halpa ja nopeasti yleistynyt tietokoneluokka. Puolijohdemuistien läpimurto tapahtui aivan 1960-luvun lopussa. Seuraava laadullinen harppaus tapahtui vuonna 1971 kun Intel toi markkinoille ensimmäisen mikroprosessorin, neljän bitin 4004:n. Mikroprosessori on puolijohdekomponentti, joka sisältää ne piiriratkaisut, jotka tarvitaan tietokoneen aritmeettisten ja loogisten toimintojen toteutuksessa. Mikrotietokone on yleensä mikroprosessorin perustalle rakennettu tietokone oheislaitteineen. Ensimmäinen mikrotietokone tuotiin markkinoille 1970-luvun puolivälin jälkeen (ks. tarkemmin esim. Ernst 1983, Dosi 1984).

Elektroniikan kehitystä ovat voimakkaasti hallinneet puolijohdekomponenttien antamat mahdollisuudet. 1950-luvun erilliskomponenteista (transistoreista ja diodeista) on edetty 1980-luvun LSI- ja VLSI-komponentteihin, joissa yhdelle puolijohdepalalle on integroitu $10^{4}-10^{5}$ transistoritoimintoa sisältäviä elektronisia järjestelmiä. Viimeiset kymmenen vuotta puolijohdemuistien ja mikroprosessoreiden kehitys on ollut eksponentiaalista. Loogisten toimintojen tiheys mikropiirissä on kaksinkertaistunut noin kahden, kolmen vuoden välein. "Integroinnin kehityksen havainnollistamiseksi voidaan tarkastella yksityisen transistorin valmistuksen mittatarkkuutta, niin sanottua viivaleveyttä. Vuonna 1980 se oli noin 3 mikrometriä. Vuonna 1984 se oli pienentynyt jo 1 mikrometriin yksityisten transistoreiden ollessa likimain bakteerien kokoisia. Vuonna 1990 transistoreiden koon oletetaan jo olevan virusten kokoluokkaa ja vuonna 2000 on todennäköistä, että transistorin tavoin toimivia rakenteita voidaan valmistaa 
makromolekyyleiksi”' (Otala 1984, 52). Ilman uusia perusinnovaatioita kehityksen oletetaan olevan hitaampaa 1990-luvulla kuin 80-luvulla (Ranta et al. 1984).

Tämän kehityksen seurauksena mikroprosessoreiden suorituskyky ja luotettavuus ovat erittäin nopeasti kasvaneet. Puolijohdemuistien kapasiteetti on moninkertaistunut. Tehon kulutus on laskenut. Ja mikä oleellisinta: transistoritoimintoa kohden laskien puolijohdekomponenttien hinta on jatkuvasti nopeasti laskenut. Tämä ei useinkaan merkitse, että mikroprosessoreihin perustuvien laitteiden hinnat laskisivat, mutta laitteiden suorituskyvyn moninkertaistuessa niistä saadaan huomattavasti enemmän irti. Tässä mielessä ne tulevat taloudellisesti entistä kannattavammiksi.

Puolijohdetekniikan huimaa kehitystä tarkasteltaessa on kuitenkin otettava huomioon, että sen käytännön soveltaminen on riippuvainen kunkin sovellutusalan ohjelmistojen ja toisaalta mittaus-, säätö- ja ohjausjärjestelmien kehityksestä. Näiden kehitys ei ole ollut eksponentiaalista.

Elektroniikkatekniikan nopeakaan sisäinen kehitys ei sinänsä oikeuta vielä puhumaan koko teollisuuden tai yhteiskunnan kannalta keskeisestä teknologisesta murroksesta. Tähän tarvitaan vielä lisäperusteluja. Niitä on kuitenkin löydettävissä ja näyttää todella siltä, että voimakas murros on alkanut nimenomaan 1970-luvulla:

- Ase- ja avaruusohjelmat olivat alusta alkaen elektroniikka-alan määrällisesti ja laadullisesti tärkeimmät sovellutusalueet. Vasta 1970luvulle tultaessa kehittyivät julkisen tietoliikennesektorin lisäksi kaupallisesti todella merkittävät elektroniikan teolliset ja kaupallis-hallinnolliset sovellutusalueet.

- Vielä 1960-luvulla tietokoneita käytettiin teollisuudessa pääasiassa kirjanpidollisissa tehtävissä. Lähinnä 1970-luvun alkuun ajoittuu prosessiteollisuuden automaation muut- tuminen tietokonepohjaiseksi valvonta- ja ohjaustoiminnaksi. 1970-luvun lopulla alkoi yleistyä tietokonepohjainen tuotannon suunnittelu. Samalla suurelta osalta mikroprosessoreihin perustuva tuotannon ohjaus ja toteutus leviää prosessiteollisuudesta kappaletavaratuotantoon ja kaupallis-hallinnollisille aloille.

- Olennaista on, että 1970-luvulla kehitetty mikroprosessoritekniikka muutti ratkaisevasti järjestelmien ja laitteiden toteutusta. Elektroninen tietojenkäsittely tuli ulos tietokonekeskuksista. Mikroprosessorit ovat vieneet sen yksittäisiin laitteisiin, koneisiin ja osaprosesseihin. "Lähitulevaisuudessa on vaikeaa kuvitella konetta tai laitetta, jossa ei olisi elektroniikkaa, tavallisimmin kehittyneeseen tietotekniikkaan perustuvaa prosessoriohjausta sekä tehoelektroniikkaan perustuvaa moottoreiden säätöjärjestelmää" (Otala 1984, 63). Näin elektroniikka-alasta vähitellen muodostuu useimmat teollisuuden alat läpäisevä "poikkiteknologia". Yhä useamman alan prosessit ja tuotteet ovat "mekatroniikkaa". Tähän liittyen ovat nopeasti yleistymässä tilaus- ja sovitepiirien valmistus sekä eri aloilla toimivien yritysten omat sisäiset puolijohdetehtaat.

- Elektroniikan standardikomponenttien valmistus on kehittynyt yhä pääomavaltaisemmaksi massatuotannoksi, joka kykenee tyydyttämään nopeasti kasvavan komponenttitarpeen. Myös elektronisten laitteiden kokoonpano on koneistumassa.

Tiivistettynä: 1970- ja 80-luvun alun teknologisen murroksen keskeisin osa on ollut teollisuuden ja enenevässä määrin myös kaupallis-hallinnollisen sektorin "Durchelektronisierung"! Samalla elektronisista tuotteista tulee entistä useammin aseiden tai lelujen asemasta työkaluja — mikä on normaali järjestys teknologioiden historiassa. Elektroniikan sovelta- 
minen ei tosin näytä luovan paljoakaan uusia tuotteita. Elektroniikan sovellutukset tekevät kuitenkin teollisuuden koneista, tietoliikennevälineistä ja monista kulutustavaroista monipuolisempia ja varmempia, minkä seurauksena tuottavuus kasvaa ja mahdollistuu uusia toimintoja.

Näillä perusteilla olisin valmis hyväksymään väitteen teollisuuden teknologisen systeemin muutoksesta. 1990-luvun teknologinen systeemi perustuu erittäin suurelta osin elektroniseen infrastruktuuriin ja tuhansiin sovellutuksiin eri aloilla. Mutta: vaikka yksittäisissä työpisteissä tai kulutusmuodoissa muutokset saattavat olla nopeita, kokonaisuus muuttuu hitaasti. Eikä teknologisen systeemin muutos ole riippumaton muusta yhteiskunnallisesta kehityksestä.

\section{"Savupiipputeollisuudesta korkeaan teknologiaan"}

Selvimmin elektroniikkaan perustuva teknologinen murros näkyy kehittyneiden kapitalististen maiden teollisuuden eri tuotannonalojen kasvunopeuksien eroina. Muoti-ilmaisuja käyttäen: kasvun painopiste on siirtynyt perinteisestä ns. savupiipputeollisuudesta ns. korkean teknologian tuotteiden tuotantoon.

Yhdessätoista tärkeimmässä OECD-maassa kasvoivat seuraavat toimialat 1970 -luvun aikana tuotannon määrällä mitattuna kaikkein nopeimmin:

- radiot, televisiot ja tietoliikennevälineet (kasvu 8,1\%/v)

- tieto- ja konttorikoneet $(7,5 \%)$

- lääkkeet $(6,8 \%)$

- autot $(5,7 \%)$

- kemikaalit $(5,0 \%)$

- instrumentit $(4,9 \%)$

- kumi- ja muovituotteet $(4,3 \%)$
Alle prosentin vuosivauhtia kasvoivat tekstiili-, metallin perus-, puunjalostus- ja savi-, lasi- ja kiviteollisuus sekä maaöljyn jalostus (OECD 1984 e).

Suomessa nopeimmin ja hitaimmin kasvaneet alat ovat suurin piirtein samat kuin suurissa OECD-maissa. Tosin Suomen jäljessä tuleminen näkyy siinä, että nopeasti kasvaneiden alojen joukossa on edelleen joitakin perusteollisuuden aloja. Tämä näkyy taulukosta 3 , jossa on esitetty vuosina $1970-83$ työllisyy-

Taulukko 3. Nopean ja hitaan kasvun alat Suomen tehdasteollisuudessa 1970-83 henkilökunnan määrän kehityksellä mitattuna.

Nopeimman kasvun alat

Henkilökunnan määrä 1983, kun $1970=100$

3825 Tieto- ja konttorikoneiden v. 396

3522 Lääkkeiden $v$. 220

385 Instrumenttien v. 217

3832 Radioiden, televisioiden ja tietoliikennevälineiden $\mathrm{v}$. $\quad 163$

353 Maaöljyn jalostus 163

351 Kemikaalien v. 155

354 Maaöljy- ja kivihiilituott. v. $\quad 144$

342 Graafinen tuot., kustannustoim. 135

384 Kulkuneuvojen v. 130

381 Metallituotteiden v. 129

Hitaimman kasvun alat

324 Kenkien v. 98

322 Vaatteiden $v$. 98

355 Kumituotteiden v. 95

314 Tupakkatuotteiden v. 93

362 Lasin ja lasituotteiden v. $\quad 91$

313 Juomien v. 87

331 Puutav. paitsi -kalusteiden v. $\quad 86$

323 Nahka-, turkis- yms. tuotteiden

321 Tekstiilien v. 65

361 Posliiniteost. ja saviast. v. 59 
den kehityksellä mitattuna nopeimmin ja hitaimmin kasvaneet alat. Kymmenen nopeimmin kasvaneen alan osuus tehdasteollisuuden henkilöstöstä vuonna 1983 oli $28 \%$.

Yleisesti nopeimmin näyttävät siis kasvavan elektroniikkatuotteita tai elektroniikkaa sisältäviä laitteita valmistavat alat sekä hienokemiallinen teollisuus. Hitaasti kasvavilla aloilla elektroniikan vaikutus näkyy lähinnä prosessien koneistamisessa ja automatisoimisessa.

\section{Työn tuottavuuden kasvuvauhti ei ole}

\section{nopeutunut}

Edellä esitetyistä työllisyyttä koskevista luvuista ja teknologisen murroksen kuvauksesta on saattanut syntyä mielikuva, että työn tuottavuuden kasvuvauhti olisi nopeutunut 1970luvun puolivälin jälkeen ja että lisääntynyt työttömyys olisi seuraus rationalisointi-investointien nopeasta laajentumisesta. Tämä varsin yleinen mielikuva on kuitenkin väärä.

Käytettävissä olevat tilastot osoittavat, että työn tuottavuuden (tuotannon määrä/työlliset) kasvuvauhti on pikemminkin hidastunut. Jos laskelman pohjana käytetään taulukoissa 1 ja 2 esitettyjä tietoja, saadaan tulokseksi, että vain Irlannissa ja Englannissa työn tuottavuus kasvoi vuosina 1974-84 nopeammin kuin vuosina 1964-74. Sama havaitaan taulukosta 4, jossa on esitetty Suomen ja koko OECD-alueen osalta tuotannon määrän kehitys työllistä kohden tehdasteollisuudessa periodeittain $1960-82$.

Taulukko 4. Tehdasteollisuuden työn tuottavuuden keskimääräinen vuosittainen kasvuprosentti 1960-82.

$$
1960-681968-731973-791979-82
$$

$\begin{array}{lllll}\text { Koko OECD } & 4,7 & 5,1 & 2,8 & 2,2 \\ \text { Suomi } & 4,4 & 3,7 & 2,8 & 3,6\end{array}$

Lähde: OECD $1984 \mathrm{c}$.
Suomen osalta Wyatt'n (1983) tutkimuksessa esitetyt lukusarjat vahvistavat edelleen tätä johtopäätöstä. Vuodesta 1960 vuoteen 1970 tehdasteollisuuden tuotanto tehtyä työtuntia kohden kasvoi absoluuttisina lukuina tarkasteltuna lähes täsmälleen saman kuin vuodesta 1970 vuoteen 1980. Prosentuaalisesti kasvu oli näin jälkimmäisellä periodilla selvästi alhaisempi. Pääomakannan suhde tuotannon määrään (ns. pääomakerroin) on pysynyt varsin vakaana.

Osa työn tuottavuuden kasvuvauhdin hidastumisesta voidaan selittää kapasiteetin käyttöasteen alenemisella ja sillä että työntekijämäärää on ollut vaikea nopeasti pudottaa kysynnän heilahtelujen mukaan. Mutta ainakin OECD:n sihteeristön laskelmien mukaan suurissa OECD-maissa työn tuottavuuden kasvuvauhti on hieman hidastunut vaikka kapasiteetin käyttöasteen laskukin otettaisiin laskelmissa huomioon (OECD 1984 f, 89).

Toinen syy työn tuottavuuden kasvuvauhdin hidastumiseen on se, että kysynnän hitaan kasvun oloissa teollisuudessa on voitu suorittaa aikaisempaa selvästi vähemmän laajennusinvestointeja. Nopean kasvun oloissa pääomakannan uudistaminen on helpompaa kuin hitaan kasvun oloissa.

Kolmas syy työn tuottavuuden kasvuvauhdin hidastumiseen saattaa olla rakenteellinen. Tuotannon jalostusasteen kohotessa on tuotannon työvaltaisuus ehkä väliaikaisesti kohonnut. Toisaalta samaan aikaan tekstiiliteollisuuden ja muiden perinteisesti työvaltaisten alojen osuus tuotannosta on supistunut.

Tuottavuuden mittaamisen vaikeuksista huolimatta näyttää joka tapauksessa selvältä, ettei OECD-maissa nykyisin vallitseva korkea työttömyys johdu nopeutuneesta työn tuottavuuden kasvuvauhdista, siis teknologisesta työttömyydestä. Työttömyyden kasvu voi- 
daan tyydyttävästi selittää kysynnän kasvuvauhdin hidastumisesta aiheutuneella saneerauksella, joka erityisesti koettelee vanhoja teollisuusmaita, vanhoja teollisuusaloja ja vanhoja teollisuuspaikkakuntia.

\section{Pienteollisuuden uusi nousu?}

Hidastunut kasvu ja teknologiset muutokset eivät ole myöskään lopullisesti nujertaneet pienteollisuutta. Päinvastoin 1970-luvun puolivälissä alkoi Suomessa ja useissa muissakin OECD-maissa pienteollisuuden ja laajemminkin yrittäjyyden uusi nousu.

Suomen osalta pienten (henkilökunta alle $100)$, keskisuurten $(100-499)$ ja suurten (yli 500) yritysten osuutta teollisuustuotannon jalostusarvosta ja henkilökunnasta voidaan tarkastella teollisuustilaston avulla vuodesta 1963 lähtien. Tosin teollisuustilastossa eivät ole mukana alle viiden työntekijän toimipaikat. Vuodesta 1963 vuoteen 1974 suurten yritysten osuus teollisuustuotannon jalostusarvosta kasvoi tasaisesti, mutta sen jälkeen kehityksen suunta kääntyi. Kuten taulukosta 5 nähdään suurten yritysten osuus on vuonna 1982 palannut takaisin lähes vuoden 1968 tasolle.

Taulukko 5. Erikokoisten yritysten osuus teollisuustuotannon jalostusarvosta Suomessa 1963-1982, \%.

$\begin{array}{lccc}\text { Vuosi } & \text { Pienet } & \text { Keskisuuret } & \text { Suuret } \\ 1963 & 20,6 & 22,3 & 57,1 \\ 1968 & 18,0 & 22,1 & 59,9 \\ 1974 & 14,2 & 19,1 & 66,7 \\ 1982 & 17,1 & 22,1 & 60,8\end{array}$

Lähde: Teollisuustilasto, tekstitaulukko toimipaikat yhdistettyinä yrityksittäin henkilökunnan suuruuden mukaan.

Pienyritysten elpyminen näkyy hyvin myös teollisuuden henkilökunnan kehityksessä. Vuodesta 1975 vuoteen 1982 teollisuustilastossa mukana olevien pienyritysten henkilökunta lisääntyi 21500 hengellä, kun suurten yritys- ten henkilökunta väheni 19800 hengellä. Keskisuurten yritysten henkilökunta lisääntyi vastaavana aikana 1600 hengellä. Pienyritysten merkityksen kasvu johtuu pääasiassa uusien yritysten perustamisesta. Vuonna 1982 teollisuustilastossa oli mukana 5458 pienyritystä kun niitä vuonna 1975 oli ollut vain 4833 (ks. tarkemmin PKT-neuvottelukunta 1982).

Toivonen (T\&E 3/1984) näkee uuden yrittäjyyden nousun syiksi mm. laman oloissa lisääntyneen tarpeen itsensä työllistämiseen, alihankintajärjestelmän laajenemisen, uuden teknologian tarjoamat mahdollisuudet, kulutuksen eriytymisen, julkisen tuen lisääntymisen ja arvostusten muutokset. Monet näistä voidaan liittää tavalla tai toisella teollisuuden rakennemuutokseen. Kasvuvauhdin nopeasti hidastuttua perinteisempien alojen suuryritykset ovat leikanneet kannattamatonta tuotantoa (lopettamalla tuotantoa, myymällä osan toimipaikoista ja lisäämällä alihankintatoimintaa) ja keskittyneet uudistumiseen ennen kaikkea yritysostojen avulla (juridisesti erillisiksi jääneet suuryritysten tytäryhtiöt eivät näy edellä esitetyissä luvuissa). Samalla suuryritysten muutosjäykkyys on tarjonnut uusien teknologioiden ja tuoteryhmien syntymisen myötä ainakin väliaikaisesti tilaa uusille pienyrityksille. Vain osa näistä on kuitenkin varsinaisia "schumpeterilaisia" uuden teknologian siemenyrityksiä, joita teollisuuspoliitikot kautta OECD-alueen kilvan ylistävät.

Pienteollisuuden nousu ei ole dramaattinen eikä sen tarvitse olla pysyvä. Teknologioiden elinkaaria koskeneet tutkimukset ovat lähes poikkeuksetta osoittaneet, että teknologian syntyvaiheessa uudet pienyritykset näyttelevät usein keskeistä osaa. Teknologian standardisoituessa ja varmistuessa kannattavaksi suuryritykset lähtevät kilpailuun mukaan joko ostamalla hyvin liikkeelle lähteneitä pienyrityksiä tai perustamalla tuotannon mitta- 
kaavaetuja tehokkaasti hyväksi käyttäviä suurtuotantolaitoksia. Ne pienet yritykset, jotka eivät kykene kasvamaan toimialan kasvun tahdissa, katoavat markkinoilta tai tulevat ostetuiksi osaksi suurempia yrityksiä.

Nykyiseen teknologiseen murrokseen liittyy kyllä piirteitä, jotka saattavat suosia pysyvämminkin pienessä mittakaavassa tapahtuvaa tuotantoa. Tuskin jättitehtaiden aika on ohi perinteisessä prosessiteollisuudessa tai massamarkkinatuotteissa, mutta korkeamman jalostusasteen tuotannossa erikoistuneilla ja nopeasti muuttuvilla tuotemarkkinoilla joustavat tuotantojärjestelmät ja uudet elektroniikkaan perustuvat konejärjestelmät saattavat hyvinkin lisätä kilpailukykyisyyttään.

\section{Teollisuuden uusi sijoittuminen ja halpatuonnin ongelma}

Teollisuuden murrosta tulee tarkastella myös kansainvälisen työnjaon muutosten kannalta. Kansainvälisen kaupan tuotesykli-teorian mukaista olisi, että vanhojen teollisuusalojen työvaltainen tuotanto siirtyisi murroksen seurauksena kasvavassa määrin kehitysmaihin. Kysymys voi olla joko kehitysmaiden omien yritysten tuotannon laajentumisesta tai monikansallisten yritysten sijoittumisesta kehitysmaihin, joissa työvaltaisten tuotantoprosessien kustannukset muodostuvat erittäin alhaisiksi. Vanhoissa teollisuusmaissa kehitysmaiden kasvava teollisuustuotteiden vienti koetaan ns. halpatuontiongelmana. Mutta kuinka laajassa mitassa tällaista teollisuustuotteiden tuotannon uudelleensijoittumista on tapahtunut? Ja kuinka suuren osan lisääntynyt kehitysmaatuonti selittää OECD-maiden työttömyyden kasvusta?

Eräs karkea tapa tarkastella tätä kysymystä on tutkia kuinka paljon kehitysmaiden ja SEV-maiden osuus on kasvanut OECD-mai- den tuonnista viimeisten vuosien aikana. OECD-maiden koko tuonnista muiden kuin OECD-maiden osuus oli vuonna $197025 \%$ ja vuonna $198234 \%$. Valtaosa tästä muutoksesta selittyy öljyn hinnan kohoamisella, sillä samana ajanjaksona OPEC-maiden osuus OECD-alueen tuonnista kohosi $7 \%$ :sta 14 $\%$ :iin. Teollisuustuotteissa (SITC 5-8) OECD-alueen ulkopuolelta tulevan tuonnin osuuden kasvu on ollut vähäisempää. Vuonna 1970 kehitysmaiden ja SEV-maiden osuus OECD-alueen teollisuustuotteiden tuonnista oli vain $10 \%$ eikä se ollut vuonna 1982 kuin $15 \%$.

Taulukossa 6 on esitetty ne teollisuustuotteiden ryhmät, joissa on tapahtunut suurimmat muutokset 1970-luvun murroksen aikana. Taulukon tuotteet voidaan jakaa kolmeen ryhmään. Suurimmat muutokset ovat tapahtuneet tekstiili-, vaate-, nahka-, kenkä- ja kumiteollisuudessa (ns. tevanakeku-teollisuus), jossa kehitysmaiden osuus on jo perinteisesti ollut suuri. Toisena ryhmänä on muutama peruskemian ja konepajateollisuuden tuoteryhmä. Varsinainen 1970-luvun muutos on se, että myös eräissä elektroniikkaan perustuvissa tuoteryhmissä kehitysmaiden osuus on kasvanut. Kysymys on tässä pääasiassa monikansallisten yritysten pyrkimyksestä siirtää elektroniikkateollisuuteen ainakin vielä kuuluvaa työvaltaista kokoonpanoa halvan työvoiman maihin. Kuvaavana suomalaisena esimerkkinä voidaan mainita Nokian tytäryhtiön Mobiran hanke perustaa Etelä-Koreaan autopuhelimien kokoonpanotehdas, jonka tuotannosta valtaosa suunnataan Yhdyvaltain markkinoille.

Kehitysmaiden osuus OECD-maiden tuonnista on korkeampi Yhdysvalloissa ja Japanissa kuin Länsi-Euroopassa. Suomessa kehitysmaatuonnin vaikutukset ovat olleet vähäiset. Kimmo Kiljusen (1984) mukaan esimerkiksi työllisyysvaikutukset ovat olleet hyvin vähäi- 
set: "Ensinnäkin, 1970-luvun kuluessa teollisuustuotteiden kasvanut tuonti kehitysmaista vaikutti vain hyvin vähäiseltä osin Suomen kokonaistyöllisyystilanteeseen. Toiseksi, kehitysmaatuonnin aiheuttamat työllisyysmenetykset joillakin toimialoilla tuli enemmän kuin kompensoitua viennin kasvaessa. Suomen kehitysmaakaupan nettovaikutus teollisuuden työllisyyteen oli siten selvästi positiivinen. Kolmanneksi, myös kaikkein haavoittuvimmilla sektoreilla muu rakennekehitys aiheutti huomattavasti suurempia työllisyysmenetyksiä kuin kasvanut kehitysmaatuonti."
Vähintään yhtä tärkeää on muistaa että kehitysmaiden teollisuustuotteiden viennistä OECD-maihin vastaavat hyvin harvat maat, joita yleisesti kutsutaan NIC-maiksi. Näihin maihin voidaan laskea kuuluvan Latinalaisesta Amerikasta Meksiko, Brasilia ja Argentiina, Afrikasta ehkä Liberia ja Kaakkois-Aasiasta Etelä-Korea, Taiwan, Hongkong, Singapore, Malesia, Thaimaa ja Filippiinit. Vuonna 1970 näiden maiden osuus kehitysmaiden ja SEV-maiden teollisuustuotteiden viennistä OECD-maihin oli $30 \%$, mutta vuonna 1982 jo $57 \%$. Koneiden ja kuljetusvälineiden vien-

Taulukko 6. Teollisuustuotteiden (SITC 5-8) tuoteryhmät, joissa OECD-maiden osuus - OECD-alueen tuonnista on laskenut yli 5 \%-yksikköä vuodesta 1970 vuoteen 1982.

Tuoteryhmä

83 Matkatarvikkeet, laukut, kotelot yms.

85 Jalkineet

84 Vaatteet

76 Puhelin-, radio-, tv- yms. laitteet

77 Muut sähkökoneet

82 Huonekalut

88 Valokuvauskoneet ja -tarvikkeet, kellot

89 Muut valmiit tavarat

69 Tuotteet epäjalosta metallista

61 Nahka, nahkatavarat

65 Tekstiilituotteet

71 Voimakoneet ja moott.

62 Kumituotteet

81 Saniteetti-, lämmitys- ja valaistustarvikkeet

52 Epäorgaaniset kem. ain.

57 Räjähdysaineet
OECD-maiden osuus Muutos

1970

1982

\%-yksikköä

$\begin{array}{lll}71,6 & 38,5 & -33,1 \\ 85,6 & 59,3 & -26,3 \\ 69,5 & 44,7 & -24,8\end{array}$

90,2

73,6

$-16,6$

92,6

79,2

78,5

$-13,4$

89,5

97,5

87,0

- 11,0

85,7

76,7

$-10,5$

96,1

88,0

$-\quad 9,0$

73,9

65,9

- 8,1

84,0

76,4

- 8,0

97,3

91,3

7,6
$-\quad 6,0$

97,0

91,1

- 6,0

-5
$-\quad 5$

93,4

87,9

- 5,5

81,3

76,0

- 5,3

77,8

72,6

- 5,2

Lähde: OECD: Foreign trade by commodities. Volume I-II. Paris $1984 \mathrm{~h}$. 
nistä NIC-maiden osuus oli vuonna 1982 peräti $70 \%$. Kehitysmaat voidaan siis jakaa suhteellisen selvästi kolmeen ryhmään: OPECmaihin, NIC-maihin ja muihin maihin. Viimeksi mainitut maat hoippuvat jatkuvan velkakriisin partaalla ja useat Afrikan maat näyttävät yksinkertaisesti kuivuvan tuskaisesti pystyyn.

NIC-maiden joukossa Meksiko ja Argentiina ovat kohdanneet viime vuosina erittäin suuria vaikeuksia. Kaikkein nopeimmin vientiään OECD-maihin ovat lisänneet KaakkoisAasian kasarmikapitalismin maat - keskeisesti ulkomaisten investointien avulla. Kun lisäksi Japanin ja Yhdysvaltain länsirannikon kasvu on ollut nopeampaa kuin kasvu LänsiEuroopassa, on tullut muotiin sanonta, että maailmankaupan painopiste siirtyy teollisuuden murroksen seurauksena Atlantilta Tyynelle Merelle.

Siis: vaikka 1970-luvun murroksen seurauksena kehitysmaiden osuus OECD-alueen teollisuustuotteiden - jopa eräiden elektroniikkatuotteiden - tuonnista on lisääntynyt, on ehdottomasti liioiteltua puhua kehitysmaiden nousevan teollisuuden muodostamasta suuresta uhkasta vanhoille teollisuusmaille. Missään tapauksessa OECD-maiden kasvaneita työttömyyslukuja ei voida selittää lisääntyneellä tuonnilla kehitysmaista - ehkä tevanakekuteollisuutta lukuunottamatta. Kehitysmaiden itsenäinen teollistuminen antaa yhä odottaa itseään.

\section{Suomen teollisuuden hyvä kehä}

Lukuvyörytyksen lopuksi vielä muutama sana Suomesta tarkemmin. Kuten Konsensuslandian ihailijat hyvin tietävät, Suomen teollisuus on menestynyt suhteellisen hyvin teollisuuden murroksen melskeessä. Tosin vuosien 1975-78 lama oli Suomessa poikkeuksellisen syvä. Teollisuuden hyvästä menestyksestä ker- tovat esimerkiksi seuraavat tiedot:

- Taulukossa 1 esitettyjen tietojen perusteella voidaan laskea, että vuosina $1964-74$ Suomen teollisuuden kasvuvauhti oli Japanin, Espanjan ja Kreikan jälkeen neljänneksi nopeinta ja vuosina 1974-84 Irlannin ja Japanin jälkeen kolmanneksi nopeinta.

- Vaikka OECD-maiden osuudet ovat yleensä laskeneet OECD-alueen kokonaistuonnista, on Suomen osuus kasvanut vuosien 1970-72 1,09 \%:sta vuosien 1980-82 $1,13 \%$ :iin.

- Suomen teollisuuden osuus koneiden ja kuljetusvälineiden maailmanviennistä on noussut vuosien $1963-650,40 \%$ :sta vuosien 1980-82 0,58 \%:iin. Koneiden ja kuljetusvälineiden osuus Suomen kokonaisviennistä oli vuonna $196512 \%$, mutta vuonna 1983 jo 25 $\%$. Samana aikana näiden tuotteiden viennin ja tuonnin suhde on kohonnut 0,3:sta 0,8:aan.

- Suomen osuus ulkomaalaisille myönnetyistä patenteista Yhdysvalloissa on kasvanut vuosina 1964-82 OECD-maista Japanin jälkeen toiseksi nopeimmin. Suomen osuus oli vuosina $1964-660,2 \%$ ja vuosina $1980-82$ $0,4 \%$.

- Suomen kokonaistutkimuspanos on kohonnut 1970-luvulla OECD-maista Japanin ja Itävallan jälkeen kolmanneksi nopeimmin. Suomen osuus OECD-maiden kokonaistutkimuspanoksesta oli vuonna $19710,27 \%$ mutta vuonna 1981 jo $0,36 \%$.

Kaikki nämä luvut tukevat käsitystä, että Suomen teollisuus on teollisuuden murroksen oloissa kyennyt jonkin verran kuromaan umpeen kapitalistisen maailmantalouden kärkimaiden teknologista etumatkaa. Mistään dramaattisesta aseman parantumisesta ei toki ole kysymys ja kehitykseen on liittynyt monia ongelmia. Suhdannevaihtelut ovat olleet jatkuvasti Suomessa erittäin suuria. Työttömyysas- 
te on noussut suuresta siirtolaisuudesta huolimatta ja on tällä hetkellä korkeampi kuin esimerkiksi Ruotsissa, Norjassa tai Itävallassa. Myös alueellisesti Suomen kehitys on ollut varsin epätasaista (ks. laajemmin Kosonen, Lovio, T \& Pekkarinen 1984).

Jos lähdetään hakemaan makrotaloudellisia selityksiä Suomen teollisuuden suhteellisen hyvälle menestykselle, niin niitä on todennäköisesti löydettävissä kolmelta suunnalta (ks. tarkemmin Lovio 1985):

- Teknologian tuonti ja jäljessä tulevan edut: Suomeen on tuotu viime vuosikymmeninä paljon modernia teknologiaa ei-riippuvassa muodossa, mikä on tarjonnut kohtuullisen perustan itsenäiselle soveltamiselle ja kehittämiselle.

- Metsäteollisuuden ja perusteollisuudesta huolehtineiden yhtiöiden, joista suurin osa on valtioenemmistöisiä yhtiöitä, perinteisen osaamisen ja uuden teknologian leikkauspisteistä on löytynyt Suomen teollisuudelle uusia sovellutus- ja erikoistumisalueita.

- Neuvostoliiton ja Ruotsin markkinat ovat kotimaisen kysynnän ohella luoneet riittävän lähtökohdan uusien korkean teknologian tuotteiden tuotannon kehittämiselle ja viennin maarakenteen monipuolistamiselle.

Erityisesti 1970-luvun lopussa ja 1980-luvun alussa Suomen teollisuuden keskimääräistä nopeampi kasvunopeus on pitkälti perustunut kasvaneen öljylaskun maksamisesta aiheutuneeseen vientiin Neuvostoliittoon. Neuvostoliiton osuus Suomen viennistä nousi vuosien 1973 ja 1983 välisenä aikana $11,7 \%$ :sta 26,2 $\%$ :iin. Teknologisen kehityksen kannalta on merkittävää, että vuonna 1983 peräti $50 \%$ Suomen koneiden ja kulutusvälineiden viennistä meni Neuvostoliittoon. Suomi on Japanin ja Saksan liittotasavallan jälkeen OECDmaista kolmanneksi tärkein näiden tuotteiden toimittaja Neuvostoliittoon.

Mutta suomalaiset yritykset ovat menesty- neet myös länsiviennissä. Ja asemien vahvistamiseksi näillä markkinoilla suomalaisten yritysten kansainvälistymiskehitys on alkanut laajemmassa mitassa 1970-luvun murroksen seurauksena. Vuonna 1979 ensimmäisen kerran suomalaisten yritysten lukumäärä ulkomailla ylitti ulkomaisten yhtiöiden lukumäärän Suomessa. Vuosina 1975-77 Suomesta tehtiin suoria sijoituksia ulkomaille yhteensä 507 milj. mk, vuosina 1978-80 1231 milj. mk, mutta vuosina $1981-83$ jo 3188 milj. mk (Teollisuuden keskusliitto 1984, Aintila \& Boldt 1984).

Kansainvälistymiskehityksen kärjessä ovat suuret vientiyritykset. Niiden strategiassa 1970-luvun murros näyttääkin aiheuttaneen yleisesti selvän muutoksen. 1970-luvun alussa monet suuryritykset tähtäsivät tuotannon diversifioimiseen lähinnä kotimarkkinoiden pohjalta oman uuden tuotannon kehittämisen tai pienehköjen yritysostojen avulla. Monet näistä yrityksistä epäonnistuivat (ks. esim. Honko et al. 1982). Tämän seurauksena on painopiste siirtynyt suuriin yritysostoihin pääasiassa tutuilla toimialoilla ulkomailla ja kotimaassa. Kasvu ja kannattavuuden parantaminen pyritään hankkimaan ostamalla markkinaosuuksia vahvoimmiksi ja lupaavimmiksi koetuilla aloilla. Pääkohteena ovat olleet pohjoismaiset ja ennen kaikkea Ruotsin markkinat, mutta aivan viime vuosina myös Yhdysvaltain, Englannin ja Saksan liittotasavallan markkinat. Tämän kehityksen kansantaloudellisia seurauksia ei ole perusteellisesti selvitetty, vaikka vaikutukset saattavat hyvinkin olla vähintään EEC-sopimuksen luokkaa. Tähän asti yritysostoja on seurannut lähinnä iloinen kohahdus: nyt suomipoika ostaa itsensä maailmankartalle!

\section{So what?}

Palaset on nyt pöydällä, mutta syntyykö niis- 
tä ymmärrettävää kuviota? Paljonko olennaisia paloja on vielä kateissa? Esille asetetuista palasista alustava yhteenvetokuvaus voisi olla seuraava:

Teollisuuden kasvuvauhti on pudonnut alle puoleen 1960-luvun tasosta. Käynnissä on teknologinen murros, joka ilmenee monien vanhempien tuotannonalojen kriisiytymisenä ja koko talouden teknisen perustan "elektronisoitumisena". Uudet teknologiset mahdollisuudet ovat osaltaan synnyttäneet ainakin väliaikaisen pienteollisuuden uuden nousun. OECD-maista murros koettelee voimakkaimmin Länsi-Euroopan vanhoja teollisuusmaita. Osa työvaltaisesta tuotannosta siirtyy kehitysmaihin, mutta tämä tuotanto on suurelta osin vanhojen teollisuusmaiden suuryritysten kontrolloimaa. Kaakkois-Aasian kasarmikapitalismin maat ovat nopeimmin lisänneet tuotantoaan. Kasvun hidastuttua työttömyys on kolminkertaistunut viimeisen kymmenen vuoden aikana OECD-maissa. Työttömyyden kasvu ei johdu työn tuottavuuden kiihtyneestä kasvusta tai lisääntyneestä halpatuonnista, vaan yksinkertaisesti tuotannon kasvun hidastumisesta ja samanaikaisesta työvoiman tarjonnan hitaasta lisääntymisestä.

Tämä on kuitenkin vain karkea kuvaus. Miksi näin on tapahtunut tai miten tapahtunutta pitäisi tulkita? Todettakoon tässä vain eräitä periaatteellisia lähtökohtia (vrt. Kosonen 1984).

Ensinnäkin näyttäisi järkevältä pitää mielessä, että teollisuuden kasvu vuosien 194874 välisenä aikana oli poikkeuksellisen voimakasta (vrt. kuva 1, lainattu Bieshaar \& Kleinknecht 1984). Tuon "kultakauden" muodostumiselle loivat edellytyksiä monet tekijät, joista mainittakoon vain 1930 -luvun laman ja sotavuosien synnyttämän kuopan täyttäminen, uudet teknologiset mahdollisuudet, kansainvälisen kaupan laajentuminen sekä työvoiman voimakkaan kysynnän perustalla tapahtunut kulutustason nousu. Kysymys on siis paluusta kapitalismin kehitykselle tyypillisemmälle kehitysuralle.

Toiseksi vaikka tässä esityksessä on painotettu teknologisten muutosten merkitystä, ei näyttäisi mahdolliselta selittää tapahtunutta yksinkertaisella innovaatiopohjaisella pitkien aaltojen teorialla. Elektroniikka-alan kehitys on vienyt kasvuvoimaa heti sodan jälkeen käyttöönotetuilta tuotteilta ja tuotantomenetelmiltä ja luonut uusia aikaisemmasta poikkeavia kasvumahdollisuuksia, mutta murros on niin hidas ja niin riippuvainen kokonaisyhteiskunnallisesta kehityksestä, että selitysyritys, joka perustuisi elektroniikka-alasta syntyviin aaltoihin on varmasti yksipuolinen.

Kolmanneksi kasvun hidastumisessa ei ole kysymys joidenkin yksittäisten "kasvutekijöiden" tai eksogeenisten olosuhteiden muutoksesta, vaan pikemminkin siitä, että ne ehdot, jotka tukivat voimakasta kasvuvaihetta, ovat kuluttaneet itsensä loppuun. Hyvä kehä on murentunut vähitellen monesta kohdasta. Esimerkiksi kriisin aineksina ovat sekä tuotteiden realisointiongelmat että kustannusten kohoaminen. Kehän mureneminen kiteytyy siihen, että yrityksillä on vaikeuksia löytää riittävän varmasti riittävän suuren voiton tuottavia investointiprojekteja. On varmempaa käyttää kasautuneet voittovarat yritysten ostamiseen ja finanssisijoituksiin.

Lopuksi on muistettava, että eri maat myös OECD-alueella kulkevat eri ajoissa ja että talouspolitiikkojen eroilla on ollut oma roolinsa.

Kapitalististen maiden talouspolitiikassa murros on selvästi koventanut otteita. Poliittiset linjat ja kovuusasteet vaihtelevat maasta toiseen, mutta uuden nousun edellytyksiä on kuitenkin varsin samansuuntaisesti haettu seuraavasti: sosiaalisesti kasvulle pyritään luomaan edellytyksiä purkamalla osia hyvinvointivaltiosta ja kärjistämällä tulonjakomekanis- 

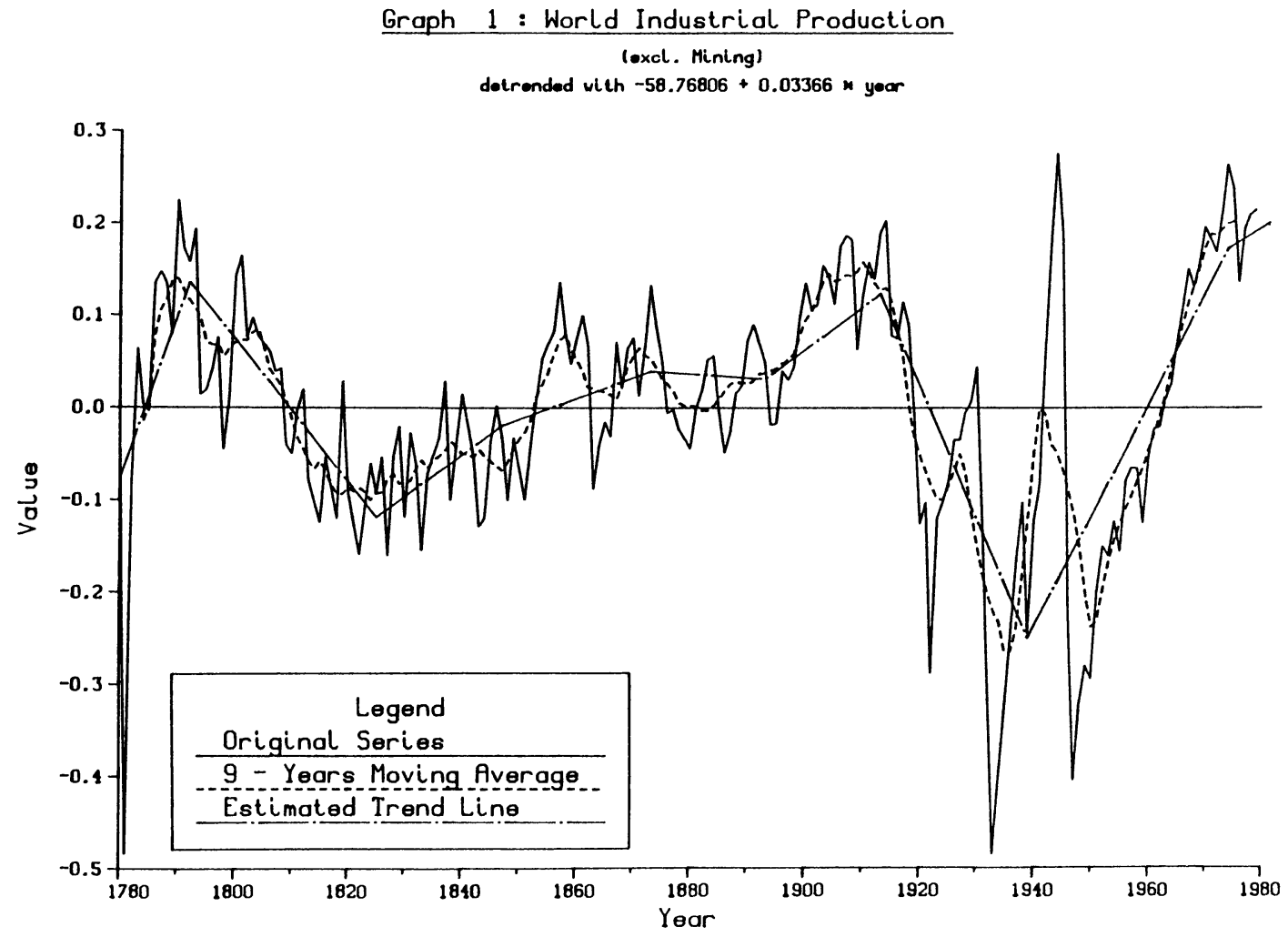

meja; teknologisesti kasvulle pyritään luomaan edellytyksiä suuntaamalla voimakkaasti varoja uuteen teknologiaan, ennen kaikkea elektroniikan sovellutuksiin; kaupallisesti edellytyksiä pyritään luomaan ottamalla käyttöön uusia piiloprotektionismin muotoja ja murtamalla heikkojen asemia kansainvälisessä työnjaossa.

Lyhyellä aikavälillä on vaikea uskoa tämän strategian menestykseen. Inflaatiovauhti on tosin OECD-maissa pudonnut $5 \%$ :n tasolle 1970-luvun puolivälin reilusti yli $10 \%$ :sta, mutta muutoin virallisten ennusteiden tämän hetkinen optimismi vaikuttaa katteettomalta. Todennäköisempää on, että vuosina 1986-87 edessä on jälleen syvä lama.

Tulevaisuus on kuitenkin avoin. Kriisit aina uudistavat taloutta - suuntaan tai toi- seen. Nykyistä tasapainoisempi kehitysura saattaa löytyä vallitsevankin politiikan tuloksena. Huomattavasti miellyttävämpää kuitenkin olisi, jos maailmantalouden tervehtyminen tapahtuisi asevarustelutuhlauksen lopettamisen, ekologisesti kestävien uusien tuotantomenetelmien käyttöönottamisen ja kehitysmaiden jaloilleennostamisprojektin kautta. 1930-luvun lama synnytti OECD-maissa "sekatalouden" idut. Entä nyt?

\section{Kirjallisuus}

Aintila, H. \& Boldt, P.J.: Monikansallinen yritystoiminta ja Suomi. TTT - Katsaus 1/1984.

Bieshaar, H. \& Kleinknecht, A.: Kondratieff long waves in aggregate output? IIASA CP-84-34. August 1984. 
Dosi, G.: Technical change and industrial transformation. The theory and an application to the semiconductor industry. Hong Kong 1984.

Economic growth in a nordic perspective. $\mathrm{D} \emptyset \mathrm{R} /$ Sekretariatet, ETLA, IFF, IUI, IØI. Helsinki 1984.

Ernst, D.: The global race in microelectronics. Frankfurt am Main 1983.

Freeman, C. et al.: Unemployment and technical innovation. London 1982.

Honko, J. et al.: Yrityksen investointiprosessin kriittiset kohdat. Joensuu 1982.

Jeskanen-Sundström, H.: Tietoja informaatioammateista ja informaatiosektorin tuotannosta. $\mathrm{Ti}$ lastokeskus. Muistio 88. 20.10.1983.

Kiljunen, K.: Kehitysmaakaupan työllisyysvaikutukset Suomessa. TTT-Katsaus 3/1984.

Kosonen, P.: Tilapäinen häiriö vai lopun alku? Sosiologia $1 / 1984$.

Kosonen, P., Lovio, T. \& Pekkarinen, J.: Den finska modellen: förändringar och förvittring eller kontinuitet och allmängiltighet? Nordisk tidskrift för politisk ekonomi 15/16-1984.

Lovio, R.: Om den finländska industrins ställning i den internationella teknologiska arbetsfördelningen - kommer den goda cirkeln att brytas? STIU-projektin työpapereita 1. Espoo 1985.

OECD: Main economic indicators. Historical statistics 1964-1983. Paris 1984 a.

OECD: Main economic indicators. October 1984. Paris $1984 \mathrm{~b}$.
OECD: Economic outlook. Historical statistics 1960-1982. Paris 1984 c.

OECD: Employment outlook. September 1984. Paris $1984 \mathrm{~d}$.

$O E C D$ : Science and technology indicators. Working paper 4. DSTI/SPR/84.49. Paris 1984 e.

$O E C D$ : Draft overall report on productivity in industry. DSTI/IND/84.12. Paris $1984 \mathrm{f}$.

OECD: Foreign trade by commodities. Volume I-II. Paris 1984 h.

Otala, M.: Tietotekniikka tuotteissa. Teoksessa Tietotekniikka 1990-luvulla. SITRA B 78. Helsinki 1984.

Perez, C.: Structural change and assimilation of new technologies in the economic and social systems. Futures, October 1983.

PKT-neuvottelukunnan raportti. Helsinki 1982.

Ranta, J. et al.: Komponenttiteknologian kehityksen vaikutukset sähkö- ja elektroniikkateollisuuteen. Osa A - yhteenvetoraportti. VTT. Espoo 1984.

Teollisuuden keskusliitto: Teollisuuden kansainvälistyminen. Keskustelumuistio 12. Helsinki 1984.

Toivonen, T.: Yrittäjien uusi nousu? Tiede \& edistys $3 / 1984$.

Työvoimakatsaus 3/1984.

Wyatt, G.: Multifactor productivity change in finnish and swedish industries, 1960 to $1980 . E T$ LA B 38. Helsinki 1983. 